\title{
A new damselfly genus and species from Baltic amber (Odonata: Zygoptera: Euphaeidae)
}

\author{
Wolfgang Ferwer ${ }^{1}$ and André $\mathrm{Nel}^{2, *}$ \\ ${ }^{1}$ Römerfeld 10, 51467 Bergisch Gladbach, Germany \\ ${ }^{2}$ Institut Systématique Évolution Biodiversité (ISYEB), Muséum national d'Histoire naturelle, CNRS, Sorbonne Université, Université \\ des Antilles, EPHE, 57 rue Cuvier, CP 50, 75005 Paris, France
}

Received: 18 October 2019 / Accepted: 23 April 2020 / Published online: 22 December 2020

\begin{abstract}
The new euphaeid genus and species, Wolfgangeuphaea ferweri Nel, are described from the Middle Eocene Baltic amber. It belongs to the Paleogene subfamily Eodichrominae. This new discovery confirms to remarkable past diversity of this family that contains now as many extinct genera and recent ones. They were distributed in North America and Europe, while the family is now-a-day only present in the Old World. There seems to have been a "replacement" of the Euphaeidae by the Calopterygidae during the latest Oligocene and the Neogene.
\end{abstract}

Keywords: Insecta / Eodichrominae / Middle Eocene / gen. et sp. nov / past diversity

Résumé - Un nouveau genre et espèce de Zygoptère de l'ambre balte (Odonata: Zygoptera : Euphaeidae). Le nouveau genre et la nouvelle espèce d'Euphaeidae, Wolfgangeuphaea ferweri Nel, sont décrits de l'ambre éocène moyen de la Baltique. Il appartient à la sous-famille paléogène Eodichrominae. Cette nouvelle découverte confirme la diversité passée remarquable de cette famille qui compte maintenant autant de genres éteints que de genres récents. Ceux-ci étaient distribués en Amérique du Nord et en Europe, tandis que la famille n'est actuellement connue que de l'Ancien Monde. Il semble qu'il y ait eu un « remplacement» des Euphaeidae par les Calopterygidae au cours de l'Oligocène supérieur et du Néogène.

Mots clés : Insecta / Eodichrominae / Eocène moyen / gen. et sp. nov / diversité passée

\section{Introduction}

If the small damselfly family Euphaeidae is supposed to have emerged during the Cretaceous (Dumont et al., 2005), its relatively diverse fossil record goes back only into the Paleocene-Eocene. It comprises nearly as many fossil genera as extant ones, as compressions in rocks and in the Eocene Baltic amber (Nel et al., 2013). Nevertheless, fossils of these rather large damselflies remain exceptional, especially in amber. Therefore, the present description of a new, wellpreserved fossil of this family from the Baltic amber is of great interest to confirm the remarkable past diversity of this family.

\section{Materials and methods}

The fossil is included in a relatively clear piece of amber, together with an adult Chironomidae and a Brachycera. Its ventral surface is darkened by organic remains.

*Corresponding author: anel@mnhn.fr
The wing venation terminology is given according to Riek and Kukalová-Peck (1984), as amended by Nel et al. (1993), Bechly (1996), and Jacquelin et al. (2018), rather than the recently proposed terminology of Trueman and Rowe (2019) (see answer of Nel et al., 2019). We use the following standard abbreviations: AA: anal anterior; AP: anal posterior; arc.: arculus; Ax1 and Ax2: primary antenodal cross-veins; $\mathrm{CuA}$ : cubitus anterior; d.c.: discoidal cell; IR1 and IR2: intercalary radial veins; MA: median anterior; MAb: posterior branch of median anterior; MP: median posterior; N: nodus, "O”: oblique vein; Pt: pterostigma; RA: radius anterior; RP: radius posterior.

Dijkstra et al. $(2013,2014)$ proposed molecular phylogenetic analyses of the Odonata, but this work cannot be used to classify fossil taxa, for which we follow the only existing extensive attempt done by Bechly (1996).

\section{Systematic Palaeontology}

Order Odonata Fabricius, 1793

Suborder Zygoptera Sélys-Longchamps, 1854 

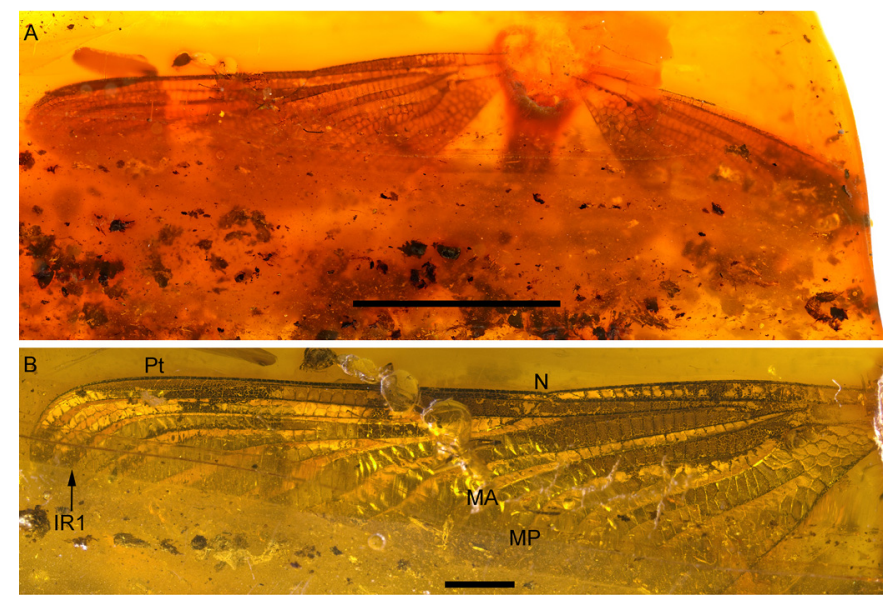

Fig. 1. Wolfgangeuphaea ferweri Nel gen. et sp. nov., holotype MNHN.F.A.71315. A: general habitus; B: hindwing. Scale bars represent $10 \mathrm{~mm}(\mathrm{~A}) ; 2 \mathrm{~mm}(\mathrm{~B})$.

Family Euphaeidae Sélys-Longchamps, 1853 (=Epallagidae Needham, 1903)

Subfamily Eodichrominae Cockerell, 1923

Genus Wolfgangeuphaea Nel gen. nov.

Type species Wolfgangeuphaea ferweri Nel sp. nov.

Diagnosis. Very long pterostigma, arculus close to Ax1, but not aligned with it; two concave longitudinal secondary veins and a net of small cells in very broad cubito-anal area; free discoidal cell; five rows of cells between AA and posterior wing margin; a very long and straight secondary concave vein between RP1 and IR1; absence of double rows of cells in area between $\mathrm{C}$ and RA distal of pterostigma.

Etymology for genus and species names. Named after the first author Dr. Wolfgang Ferwer and the genus Euphaea.

Wolfgangeuphaea ferweri Nel sp. nov.

Figure 1

Holotype. MNHN.F.A.71315 (coll. Wolfang Ferwer, a fragment of mesothorax, metathorax complete, with a well preserved hindwing and the basal half of the other; two basal abdominal segments present), stored at the MNHN, Paris.

Diagnosis. As for the genus, wings with colored areas at apex and in its middle.

Description. Thorax and abdomen poorly visible; no visible secondary genital structures on second abdominal segment (possibly a female); hindwing hyaline at base, a colored zone between arculus and distal two third of wing and another one in the apical quarter, wing $24.0 \mathrm{~mm}$ long, $6.8 \mathrm{~mm}$ wide; distance from base to arculus $2.6 \mathrm{~mm}$; nodus in a basal position, $42 \%$ of wing length, distance from arculus to nodus $7.3 \mathrm{~mm}$; from nodus to pterostigma $8.2 \mathrm{~mm}$; from pterostigma to wing apex $1.7 \mathrm{~mm}$; pterostigma very long, $5.0 \mathrm{~mm}$ long, $0.5 \mathrm{~mm}$ wide, covering 12 cells, with basal and distal sides very oblique, but basal margin even more oblique than distal margin; pterostigmal brace absent, vein RA slightly bulged and thickened along pterostigma; one row of cells in distal part of area between RA and RP1, and in area between C and RA distal of pterostigma; postnodal area basal of pterostigma narrow, postnodal crossveins numerous (about 19), not aligned with 20 corresponding postsubnodal crossveins; 19 antenodal crossveins of first row, four between primary antenodal brackets Ax1 and Ax2; some antenodal crossveins of second row distal of $A x 2$ but none between $A \times 2$ and $A x 1$; Ax 1 slightly basal to arculus; Ax2 opposite fork of RP; antesubnodal space with ca. 20 crossveins in both its basal and distal halves; nodal veinlet slightly more oblique than subnodal veinlet; kink of $\mathrm{ScP}$ at nodus very abrupt and Z-like; bases of RP3/4 and IR2 between nodus and arculus, $0.1 \mathrm{~mm}$ distal of arculus and opposite level of MAb; base of IR2 very close to midfork; RP1/ 2 arising on RP with a secondary insertion, but not fused to RA; base of RP2 opposite subnodus; no antefurcal crossveins between basal parts of RP and MA; MA, MP and RP3/4 weakly curved; postdiscoidal area widened distally with three to four rows of cells between MA and MP along posterior wing margin; all other areas between main veins distinctly broadened distally; base of IR1 six cells distal of that of RP2; IR1 basally straight but distal part curved; a long and straight concave secondary longitudinal vein between RP1 and IR1, closely parallel to IR1, two other secondary longitudinal vein more zigzagged between it and RP1 with two rows of cells between them; no oblique vein "O"; discoidal cell free quadrangular elongate, with costal side nearly straight, distal side MAb perpendicular to MP; basal closure of discoidal cell with a dorsal arcular bracket; median space free; submedian space free (only $\mathrm{CuP}$ present); subdiscoidal space free; one row of cells between MP and $\mathrm{CuA}$ in its basal part, greatly broadened distally; cubito-anal area very broad with up to six rows of cells and two concave secondary longitudinal veins between $\mathrm{CuA}$ and posterior wing margin ("accessory anal vein"); $\mathrm{CuA}$ weakly zigzagged distally but simple, ending on posterior wing margin well basal of nodus level.

\section{Discussion}

An attribution of Wolfgangeuphaea gen. n. to Caloptera Belyshev and Haritonov, 1983 is supported by the following synapomorphies: midfork recessed basally to a position between $12-26 \%$ of wing length; pterostigmal brace vein obsolete; basal closure of discoidal cell in forewings including development of a dorsal arcular bracket.

An attribution to Eucaloptera Bechly, 1996 is supported by the following synapomorphies: a rectangular discoidal cell; basal margin of pterostigma more oblique than distal margin; lestine oblique vein absent.

Affinities with Amphipterygida Bechly, 1996 are excluded because the secondary antenodal crossveins between ScP and RA distal of Ax2 are not suppressed and the antesubnodal space has crossveins in both its basal and distal halves. Philoganginae Kennedy, 1920 (Philoganga Kirby, 1890) also have these two characters but they have the base of IR2 very far distal of midfork, and RP1/2 not making a strong curve at its base, unlike in Wolfgangeuphaea gen. $\mathrm{n}$.

An attribution to Calopterygomorpha is supported by the following synapomorphies: antenodal area with very numerous antenodal crossveins that are very close together; kink of $\mathrm{ScP}$ at nodus very abrupt and Z-like; strong tendency towards a basal curving of RP $1 / 2$ which is arising on RP with a secondary insertion; discoidal cell clearly elongate.

Affinities with the Chlorocyphoidea Cowley, 1937 were excluded because the discoidal cell is not traversed by any crossvein; numerous rows of cells between MP and $\mathrm{CuA}$; 
presence of numerous rows of cells between $\mathrm{CuA}$ and the posterior wing margin; basal part of the antesubnodal space with crossveins (no "chlorocyphoid gap"); RP3/4 not distinctly waving; MA not distinctly upward curved immediately after the discoidal cell.

Wolfgangeuphaea gen. $\mathrm{n}$. has a set of characters present in Euphaeida Bechly, 1996 and Calopterygoidea Sélys-Longchamps, 1850, viz. strongly developed dorsal discoidal bracket on the distal side $\mathrm{MAb}$ of the discoidal cell and on the subdiscoidal veinlet (basal CuA). Bechly (1996) proposed this character as autapomorphy of Euphaeida Bechly, 1996, but it is also present in Calopterygoidea; RP1/2 strongly curved after its base, arising on RP with a secondary insertion, even if not fused to RA for a short distance; discoidal cell rather elongate and narrow; both rows of antenodal crossveins are strictly aligned and developed as brackets so that the two primary antenodal brackets Ax 1 and Ax2 cannot be clearly identified.

An attribution to Heliocharitidae or to Calopterygoidea (Calopterygida in Bechly, 1996, but see Fleck et al., 2012) is unlikely because the discoidal cell is free in Wolfgangeuphaea gen. n., unlike being traversed by at least one crossvein in these groups (but some Epallaginae also have a crossed discoidal cell, see below). Also, the family Heliocharitidae Tillyard et Fraser, 1939 is excluded because the primary antenodal crossveins cannot be clearly distinguished from the secondary ones and the nodal veinlet is as oblique as the subnodal veinlet. An attribution to Calopterygoidea Sélys, 1850 is also unlikely because the submedian space (especially the subdiscoidal cell) is freee, so that the CuP-crossing is identifiable, unlike in this superfamily.

Within Euphaeida, Polythoridae are excluded for the discoidal cell not touching RA. Within Epallagoidea Needham, 1903, second group of Euphaeida, the base of IR2 very close to midfork would exclude affinities with Zacallitidae Cockerell, 1928 and Epallaginae Needham, 1903 (Cockerell, 1928).

Further significant distinctions from all extant Euphaeidae are the enlarged cubito-anal area with accessory concave "anal" veins (synapomorphy with Eodichrominae); the approximation of Axl and Ax2 (synapomorphy with Eodichrominae); the absence of antefurcal crossveins between the basal parts of RP and MA (synapomorphy with Eodichrominae).

Wolfgangeuphaea gen. n. differs from Parazacallites aquisextanea Nel, 1988 in the quite longer pterostigma, position of the arculus close to Ax1, but not aligned with it; and the less developed longitudinal secondary veins in cubito-anal area (Nel, 1988). Wolfgangeuphaea gen. n. differs from Eodichroma mirifica Cockerell, 1923 in the quite broader cubito-anal area; longer pterostigma, and its more basal position of the nodus (Cockerell, 1923). Wolfgangeuphaea gen. n. differs from Labandeiraia Petrulevičius et al., 2007 in the different shape of cells in anal area (a net of small cells instead of a series of very long transverse cells), the longer pterostigma, the quite longer secondary concave vein between RP1 and IR1, and the absence of double row of cells in area between $\mathrm{C}$ and RA distal of pterostigma (Petrulevičius et al., 2007). Wolfgangeuphaea gen. n. differs from Ejerslevia Zessin, 2011 and Solveigia Zessin, 2011 in the very long pterostigma and very broad cubito-anal area (Zessin, 2011).

Wolfgangeuphaea gen. $\mathrm{n}$. differs from an unpublished eodichromine new genus from the Eocene of the Green River formation (Colorado, USA) in the discoidal cell free and arculus at level of Ax1 (Bechly et al., 2020).

Wolfgangeuphaea gen. n. differs from Litheuphaea carpenteri Fraser, 1955 and Litheuphaea coloradoensis Petrulevičius et al., 2007 in the broader cubito-anal area with five rows of cells between AA and posterior wing margin instead of only three, the longer pterostigma, the absence of double row of cells in area between $\mathrm{C}$ and RA distal of pterostigma, and the presence of a very long and straight secondary concave vein between RP1 and IR1 (Fraser, 1955; Bechly, 1998; Petrulevičius et al., 2007). Wolfgangeuphaea gen. n. shares with Litheuphaea ludwigi Bechly, 1998 (Eocene Baltic amber) the broad cubito-anal area, but it has two secondary concave veins in this area instead of one in L. ludwigi, it has no double rows of cells in area between $\mathrm{C}$ and RA distal of pterostigma, base of RP2 well aligned with the subnodus, and a very long and straight secondary concave vein between RP1 and IR1, not noticed by Bechly (1998).

\section{Conclusion}

The Euphaeidae are a relatively small family of damselflies compared to the Calopterygidae ( $c a$. four extant genera and 69 species vs. 17 genera and 176 species) (Davis et al., 2011). Nevertheless, the situation seems to have been different during the Paleogene, as no less than eight described fossil genera contra four for the Calopterygidae. Also, the extant Euphaeidae are restricted to the old world while they are recorded during the Paleogene in North America and Europe. Thus, this family was probably more diverse and widespread during this period than now-a-day. The present discovery confirms this assumption. Also, if an Eocene genus and species of the extant Euphaeinae is described from the Baltic amber, all other representatives of the family belong to the extinct subfamily Eodichrominae. Dumont et al. (2005) dated the diversification of the Euphaeidae ca. 110 Myrs ago and the beginning of the diversification of the Calopterygidae $c a$. 120 Myrs ago. Davis et al. (2011) proposed that the "lineage leading to Polythoridae + Calopterygidae" knew a significant upshift of diversification, but did not indicated its date. It seems to have been rather recent, during the late Paleogene and the Neogene.

\section{Taxa registration:}

Genus Wolfgangeuphaea: urn:1sid:zoobank.org: act:653498E6-ACDD-4A73-9BCF-DCE99FBB8CB7

Wolfgangeuphaea ferweri: urn:lsid:zoobank.org: act:8D12635D-C19F-402F-9235-A60E87546401

Acknowledgments. We sincerely thank two anonymous referees for their remarks on the first version of the paper.

\section{References}

Bechly G. 1996. Morphologische Untersuchungen am Flügelgeäder der rezenten Libellen und deren Stammgruppenvertreter (Insecta; Pterygota; Odonata), unter besonderer Berücksichtigung der Phylogenetischen Systematik und des Grundplanes der Odonata. Petalura 2: 1-402. Special volume. 
Bechly G. 1998. New fossil damselflies from Baltic amber with description of a new species, a redescription of Litheuphaea carpenteri Fraser, and a discussion on the phylogeny of Epallagidae. International Journal of Odonatology 1: 33-63.

Bechly G, Garrouste R, Aase A, Karr JA, Grande L, Nel A. 2020, submitted. The Damselfly Palaeofauna from the Eocene of Wyoming, USA (Insecta, Odonata, Zygoptera). Papers in Palaeontology.

Cockerell TDA. 1923. Fossil insects from the Eocene of Texas. American Journal of Science 5(5): 397-399.

Cockerell TDA. 1928. A remarkable new dragon-fly from the Eocene (Odonata). Entomological News 39: 297-301.

Davis RB, Nicholson DB, Saunders ELR, Mayhew PJ. 2011. Fossil gaps inferred from phylogenies alter the apparent nature of diversification in dragonflies and their relatives. BMC Evolutionary Biology 11: 1-10.

Dijkstra K-DB, Bechly G, Bybee SM, Dow RA, Dumont HJ, Fleck G, et al. 2013. The classification and diversity of dragonflies and damselflies (Odonata). Zootaxa 3703: 36-45.

Dijkstra K-DB, Kalkman VJ, Dow RA, Stokvis FR, Van Tol J. 2014. Redefining the damselfly families: a comprehensive molecular phylogeny of Zygoptera (Odonata). Systematic Entomology 39: 68-96.

Dumont HJ, Vanfleteren JR, De Jonckheere JF, Weekers PHH. 2005. Phylogenetic relationships, divergence time estimation, and global biogeographic patterns of calopterygoid damselflies (Odonata, Zygoptera) inferred from ribosomal DNA sequences. Systematic Biology 54: 347-362.

Fraser FC. 1955. An Odonate fossil wing from the Oligocene of Oregon. Psyche 62: 134-135.
Jacquelin L, Desutter-Grandcolas L, Chintauan-Marquier I, Boistel R, Zheng Daran, Prokop J, et al. 2018. New insights on basivenal sclerites using 3D tools and homology of wing veins in Odonatoptera (Insecta). Scientific Reports 8: 1-7.

Nel A. 1988. Parazacallitinae, nouvelle sous-famille et premier Epallagidae de l'Oligocène européen (Odonata, Zygoptera). Bulletin du Muséum National d'Histoire Naturelle 10(4): 175-179.

Nel A, Krzeminski W, Szwedo J. 2013. Elektroeuphaea gen. n., the oldest representative of the modern Epallaginae from Eocene Baltic amber (Odonata: Zygoptera: Epallagidae). Insect Systematics \& Evolution 44: 129-140.

Nel A, Martínez-Delclòs X, Paicheler J-C, Henrotay M. 1993. Les « Anisozygoptera » fossiles. Phylogénie et classification (Odonata). Martinia 3: 1-311. Numéro hors série.

Nel A, Garrouste R, Schubnel T. 2019. Response to Trueman and Rowe (2019). The wing venation of Odonata. International Journal of Odonatology 22: 115-119.

Petrulevičius JF, Nel A, Rust J, Bechly G, Kohls D. 2007. New Paleogene Epallagidae (Insecta: Odonata) recorded in North America and Europe. Biogeographic implications. Alavesia 1: 15-25.

Riek EF, Kukalová-Peck J. 1984. A new interpretation of dragonfly wing venation based upon Early Carboniferous fossils from Argentina (Insecta: Odonatoidea) and basic characters states in pterygote wings. Canadian Journal of Zoology 62: 1150-1166.

Trueman JWH, Rowe RJ. 2019. The wing venation of Odonata. International Journal of Odonatology 22: 73-88.

Zessin W. 2011. Neue Insekten aus dem Moler (Palaeozaen/Eozaen) von Dänemark Teil 1 (Odonata: Epallagidae, Megapodagrioniidae). Virgo, Mitteilungsblatt des Entomologischen Vereins Mecklenburg 14: 62-71.

Cite this article as: Ferwer W, Nel A. 2020. A new damselfly genus and species from Baltic amber (Odonata: Zygoptera: Euphaeidae), BSGF - Earth Sciences Bulletin 191: 12. 